\title{
CESTA ZVYŠOVÁNÍ KVALITY VYUČOVÁNÍ - STANOU SE UČITELÉ VÝZKUMNÍKY VE SVÝCH TŘíDÁCH?
}

\author{
ALENA SEBEROVÁ
}

\begin{abstract}
Anotace: Příspěvek je věnován problematice (auto)evaluace ${ }^{1}$ jako zásadní cestě k rưstu kvality školního vzdělávání, učení a vyučování. Zejména jsou diskutovány terminologické nejasnosti provázející snahy o obsahové a funkční vymezení pojmu (auto) evaluace, místu, jež zaujímá v metodologii pedagogických věd a ve výzkumné doméně učitelské profese.
\end{abstract}

Klíčová slova: (auto)evaluace (evaluace a autoevaluace); učitel, učitelská profese; učitel jako výzkumník; pedagogický výzkum; (auto)evaluační výzkum; akční výzkum; učitelský výzkum

Key words: evaluation; selfevaluation; teacher; teacher profession; teacher as researcher; educational research; evaluation research; action research; teacher research

Abstract: Study is focused on a problem with evaluation and self-evaluation as a fundamental way of growth of all educational field, learning and teaching. On the centre of discussion is terminological clarification of the content and functional meaning of terms evaluation and self-evaluation and its place on methodology of educational sciences and research area of teacher profession.

\section{Úvodem}

Postupující decentralizace školského systému a posilování pedagogické autonomie učitelů s sebou nese nové možnosti rozvoje kvality institucionálního vzdělávání, jež respektuje individuální potřeby, možnosti a zájmy každého jednotlivého žáka a studenta a otevírá tak cestu k jejich vnitřní motivaci k celoživotnímu učení a životě ve společnosti vědění. Autoevaluace tyto možnosti může posilovat, pokud si učitelé uvědomí její význam, budou ochotni dále se vzdělávat, avšak bude-li jim poskytnuta komplexní systémová podpora kvalitního dalšího vzdělávání, odborné pomoci a supervize a $v$ neposlední řadě také pomoc materiální a finanční. Procesy autoevaluace mohou učitelům pomoci rozpoznat a identifikovat slabá místa a problémové oblasti, které je třeba měnit, posilovat silné stránky a dále je rozvíjet, umožňuje otevřeně řešit konflikty a budovat školu jako partnerskou instituci zalo-

1 Výraz se závorkami (auto)evaluace je užíván jako zkratka nahrazující dva pojmy evaluace a autoevaluace. 
ženou na důvěře a vzájemném respektu. Problém však nastává v okamžiku, kdy se pokoušíme operacionalizovat definici (auto)evaluace $v$ kontextu učitelské profese (profesních činností učitelů) a současně s tím zachovávat prestiž pedagogického výzkumu.

Má-li být učitel expertem $v$ edukační doméně, neobejde se bez permanentně se rozvíjejících znalostí odborně argumentovat postupy a výsledky výukových procesů, význam implementovaných změn. Předpokladem je $\mathrm{k}$ tomu teoretické $\mathrm{i}$ praktické porozumění opřené nejen o kritické teoretické studium a systematickou celistvou reflexi vlastní pedagogické praxe, ale také o objektivní výsledky realizovaných (učitelských) výzkumů. Jaké místo má ve výzkumných profesních činnostech učitelů autoevaluace? Jaké postavení zaujímá v oblasti pedagogického výzkumu? Jaké konsekvence můžeme $v$ obou profesních doménách očekávat, nebudeme-li důsledně hledat odpovědi na tyto otázky? Stanou se pak učitelé výzkumníky, kteří prostřednictvím autoevaluace rídí kvalitu vlastního vyučování?

\section{(Auto)evaluace - cesta zvyšování kvality vyučování}

Pojmy evaluace a autoevaluace jsou v posledních několika letech $v$ centru diskusí jak teoretiků pedagogiky, tak učitelských praktiků. Dalo by se říci, že se oba pojmy skloňují ve všech pádech, ze všech stran se ozývají otázky: evaluujete? Kámen úrazu ovšem nastává v okamžiku, kdy si máme odpovědět na otázku, co to vlastně ta (auto)evaluace je? Jak souvisí s hodnocením, s kontrolou a tradiční školskou inspekcí? Proč je tolik zdůrazňován její význam a jakou úlohu sehrává v rozvoji školy a kvalitě jejího života? A co se konkrétního očekává od samotných učitelů a vedení školy? Není klíčovým předmětem tohoto článku důsledně analyzovat etymologické a obsahové významy a prakticistní funkce klíčových pojmů vážící se k evaluaci, autoevaluaci, hodnocení. Tomu se dnes věnují mnohé odborné i populárně naučné statě a publikace ${ }^{2}$. Považujeme za důležité poukázat na jistá rizika při nejasném a metodologicky nesprávném zaměňování obsahů zmíněných pojmů, zlehčování jejich významu i profesní náročnosti.

V těchto letech probíhající kurikulární reforma přináší školám nové možnosti spojené s novými povinnostmi. Mohou se samostatně profilovat vlastními vzdělávacími programy a nově nabytá autonomie přináší požadavky a iniciuje potřeby reflektovat a systematicky posuzovat kvalitu všech profesních činností. Evaluace je z tohoto pohledu podmínka nebo též cena, kterou musí škola za svou autonomii zaplatit. A zde je důležité se ptát, kdo nese zodpovědnost za péči o úroveň vzdělávání ve školách a kdo je kompetentní tuto úroveň posuzovat a hodnotit. V následující části textu se pokusíme stručně pojmenovat premisy procesů evaluace a autoevaluace tak, jak jsou uváděny odborníky: McBride 1995; OECD/CERI 1995; Rýdl (ed) 1997; Fischer, Schratz 1997; Bennett 2003; Nezvalová 2004; MacBeath (ed.) 2006; Donaldson (ed.) 2006).

2 Průcha 1996; Rýdl, Horská, Dvořáková 1997; Schratz 1997; Nezvalová 2004, 2006(a),(b),(c); Donaldson 2006; MacBeath,, Schratz, Meuret, Jakobsen 2006; Pol 2007. Modifikacím obsahů a významů u pojmů evaluace a autoevaluace se blíže věnuje: Bennett 2003. 
Evaluaci (evaluation) je připisován klíčový význam v možnostech zvyšování hodnoty a kvality školního života na všech jeho úrovních, jimž předchází procesy systematicky řízené, kritické reflexe podmínek, průběhu a výsledků sociálněpsychologických a pedagogických jevů a procesů. Jako zásadní je zdůrazňována potřeba sdílené, jasně definované kvality vybraných předmětů evaluace, posouditelných indikátorů a kritérií této kvality. Zatímco externí evaluace (external evaluation) umožňuje identifikovat problémy, jež si aktéři školního života (ředitelé, učitelé, žáci) neuvědomují díky „provozní nebo rutinní slepotě“, nabízí objektivní posouzení sledovaných jevů nezávislými odborníky zvenku a možnost srovnávat závěry realizovaného šetření mezi více školami (na krajské nebo státní úrovni). Autoevaluace (internal ealuation, autoevaluation/self-evaluation) ${ }^{3}$ naopak umožňuje zaměřit pozornost na problémy, které aktéři školního života vnímají jako podstatné, nabízí príležitost posoudit sledované jevy víceúhelným pohledem všech zúčastněných aktérů, identifikovat příčiny problémů a konsenzem dohodnout postupy nápravy. U externí evaluace se zpravidla jedná o krátkodobý, jednorázový proces, což neumožňuje dlouhodoběji sledovat dané jevy, posuzovat je z hlediska jejich vývoje, odhalit příčiny problémů i výsledky jejich řešení (při implementaci navržených postupů nápravy). Jako problematická je rovněž vnímána otázka identifikace učitelů a vedení školy s výsledky evaluace, včetně zvnějšku navržených korektivních opatření. Autoevaluaci je proti tomu vytýkána jistá subjektivní zaměřenost, kdy pohledem „zevnitř̆ absentuje potřeba nezúčastněného posouzení sledovaných jevů, a kde objektivitu interpretací zjištěných výsledků mohou narušit "osobní vazby" nebo obava z kritiky.

I přes skutečnost, že oba typy evaluace nesledují vždy totožné cíle, nemusí být nutně protichůdné. Naopak, měly by se vzájemně doplňovat, poněvadž sledují společný cíl: zkvalitňovat státem - školou poskytovanou výchovu a vzdělávání. Výsledky autoevaluace mohou být využity k tvorbě výchozí koncepce evaluace externí, která rovněž může recipročně vyvolat potřebu učitelů a vedení školy realizovat interní evaluační šetření. Stejně tak odborníci školní inspekce mohou spoluvytvářet tým pro plánování a realizaci autoevaluačního projektu školy a aktéři školního života diskutovat otázky externí evaluace (srov. McBride 1995; OECD/CERI 1995; Rýdl 1997; Fischer, Schratz 1997; Bennett 2003; Nezvalová 2004; MacBeath (ed.) 2006; Donaldson (ed.) 2006).

\section{Kdy (auto)evaluace není (auto)evaluace}

Termíny hodnocení (assessment) a evaluace (evaluation) jsou tak často substituovány, že je problematické rozhodnout, zda je nutné se o specifikaci obsahových rozdílů těchto pojmů pokoušet. Význam evaluace v učitelské profesi je však stále více zdůrazňován, nabyl podoby zákonem dané povinnosti a rovněž je dáván do vztahu s výzkumným šetřením. To vše jsou relevantní důvody k operacionalizaci obou pojmů.

3 Autoevaluaci spojujeme jak s procesy realizovanými individuálně učiteli ve svém vlastním vyučování, tak týmem učitelů a ředitelů (a popř. dalších aktérů) se zaměřením na jevy a procesy, jež se váží ke všem oblastem fungování školy jako organizace. 
Evaluace (evaluation) je $v$ prostém překladu $z$ angličtiny určení hodnoty, ocenění. Původ termínu můžeme hledat také v latině, kde sloveso valere označuje charakteristiky jako být silný, mít platnost, závažnost. S tak jednoduchým příměrem však nemůžeme vystačit a navíc se zde objevuje nebezpečí, že budeme zjednodušeně chápat evaluaci jako hodnocení, což není možné. Stručně shrnuto, je pedagogická evaluace definována jako proces:

- zjištování, porovnávání a vysvětlování dat charakterizujících stav, kvalitu a efektivnost vzdělávací soustavy (Pedagogický slovník Průcha, Walterová, Mareš 1998);

- systematického shromažd’ování a analýzy informací podle určitých kritérií za účelem dalšího rozhodování (Bennett 2003);

- nebo výsledek objektivního posuzování hodnoty, kvality, efektivnosti cílových programů, výsledků, prostředků, podmínek, kontextů,...(Švec 2002);

- systematického zkoumání a sledování hodnoty a efektivity určitého předmětu nebo jevu, ... na rozdíl od nahodilého prístupu hodnocení se pod evaluací rozumí systematicky plánovitý a cíleně rízený proces hodnocení a posuzování sledovaných jevů (Rýdl 1997).

Z uvedených definic vyplývají klíčové atributy evaluace jako procesu systematického, plánovitého, cíleně rízeného a objektivního posuzování nebo zkoumání hodnoty, kvality, efektivity jevů a procesů školní reality; sběru a analýzy dat / informací podle predem stanovených kritérií. Níže uvedená tabulka shrnuje zásadní rozdíly v obsazích a významech obou pojmů a dokladuje, že není možné oba pojmy volně zaměňovat nebo (auto)evaluaci vymezovat jako systematickou reflexi ${ }^{4}$.

Tab. 1.

\begin{tabular}{|l|l|}
\hline $\begin{array}{l}\text { Hodnocení } \\
\text { (assessment) } \\
\text { Jako běžné posuzování a reflexe }\end{array}$ & $\begin{array}{l}\text { Evaluace } \\
\text { (evaluation) }\end{array}$ \\
\hline $\begin{array}{l}\text { Kritéria: nejsou explicitně vymezena; } \\
\text { indikátory výkonu nejsou stanoveny a a } \\
\text { nejsou sdíleny školní komunitou; nejas- } \\
\text { ná hodnotíć kritéria }\end{array}$ & $\begin{array}{l}\text { Kritéria: vymezena explicitně a sdílena; } \\
\text { jsou jasně formulovány cíle, indikátory } \\
\text { kvality výkonu, hodnotící kritéria }\end{array}$ \\
\hline $\begin{array}{l}\text { Proces/evaluační plán: není jasně sta- } \\
\text { noven, neplánovaný, nepravidelný, ne- } \\
\text { ŕízený, nekontrolovaný }\end{array}$ & $\begin{array}{l}\text { Proces/evaluační plán: jasně stanoven } \\
\text { podle cílü, strukturovaný s předem da- } \\
\text { nými úkoly a zodpovědnostmi, plánova- } \\
\text { ný, ř́zený, kontrolovaný }\end{array}$ \\
\hline $\begin{array}{l}\text { Metody: nejsou předem stanoveny, } \\
\text { nekonzistentní, bez kontroly validity a a } \\
\text { reliability, nahodilý sběr dat, základem } \\
\text { jsou náhodné zkušenosti, analýza dat dat } \\
\text { probíhá bez stanovených kritérií }\end{array}$ & $\begin{array}{l}\text { Metody: jsou jasně určeny zdroje dat, } \\
\text { které jsou cíleně sbírány a analyzovány } \\
\text { podle daných kritérií, provádí se trian- } \\
\text { gulace metod s kontrolou jejich validity } \\
\text { a reliability }\end{array}$ \\
\hline
\end{tabular}

4 Bliže se obsahovým a metodologickým rozdílům u pojmů reflektivní vyučování, autoevaluace / autoevaluační výzkum v oblasti pedagogických věd a pedagogické praxe věnují práce $\mathrm{D}$. Ebbutta (1985); E. Ferrance (2000). 
\begin{tabular}{|l|l|l|}
\hline Závěry: subjektivní, spočívají na do- & Závěry: relativně objektivní, vychází \\
jmech a míněních, nejsou dokumento- & z široké databáze různorodých hledisek, \\
vány, nevypracovává se závěrečná zprá- & jsou dokumentovány v závěrečné zprá- \\
va, inovace jsou navrhovány nahodile a a & vě, jsou navrhovány a systematicky za- \\
bez systematické implementace & váděny inovace \\
\hline
\end{tabular}

(srov. McBride 1995; Rýdl 1997; Fischer, Schratz 1997; Nezvalová 2004)

Obsahově jasné a jednoznačné vymezení pojmů evaluace a autoevaluace není možné obcházet ani jakkoli zlehčovat, poněvadž se dostáváme na tenký led zákonem stanovených povinností učitelů a vedení škol. Konkrétně vyhláška č. 15/2005 Sb., vztahující se k zákonu č. 561/2004 Sb. o předškolním, základním, středním, vyšším odborném a jiném vzdělávání (školský zákon), stanoví náležitosti dlouhodobých záměrů, výročních zpráv a vlastního hodnocení školy. Termín vlastní hodnocení školy vyhláška bliže nespecifikuje, pouze uvádí, že je zaměřeno na "cíle, které si škola stanovila zejména $v$ koncepčním záměru rozvoje školy a ve školním vzdělávacím programu, a jejich reálnost a stupeň důležitosti" (s. 67). Dále se toto hodnocení zaměřuje na způsob, jak škola dané cíle plní, a to s ohledem na rámcový vzdělávací program a další právní předpisy. Následně je zaměřeno na ty oblasti práce školy, ve kterých dosahuje dobrých výsledků, event. kde je zapotřebí úroveň vylepšovat a následně navrhovat opatření ke změnám. Vyhláška dále velmi obecně stanoví oblasti vlastního hodnocení školy, kam řadí „podmínky ke vzdělávání; průběh vzdělávání; podpora školy žákům a studentům, spolupráce s rodiči, vliv vzájemných vztahů školy, žáků, rodičů a dalších osob na vzdělávání; výsledky vzdělávání žáků a studentů; rízení školy, kvalita personální práce, kvalita dalšího vzdělávání pedagogických pracovníků; úroveň výsledků práce školy, zejména vzhledem k podmínkám vzdělávání a ekonomickým zdrojüm"(s. 67). Pravidla a termíny vlastního hodnocení školy vyhláška konkretizuje podmínkou, že toto musí být zpracováno za období jednoho nebo dvou školních roků a jeho strukturu navrhuje ředitel školy a projednává ji s pedagogickou radou.

Jak jsem poukázala, je obsahová specifikace vlastního hodnocení školy velmi obecná, i když je zapotřebí vyzvednout, že samotný zákon tuto pravomoc školám přisuzuje a navíc zohledňuje kromě výsledků vzdělávání také jeho průběh, podmínky, vzájemné vztahy mezi všemi aktéry školy (včetně rodičů) a explicitně pojmenovává také důležitost kvality dalšího vzdělávání učitelů. Žádoucí je rovněž respektování individuálních podmínek a ekonomických zdrojů školy v poskytovaném vzdělávání. Diskutabilní je samotný termín vlastní hodnocení školy. Vzhledem k nejasnostem u pojmů evaluace a hodnocení (a současně také autoevaluace a sebehodnocení) nezdá se být toto slovní spojení príliš vhodné. Zejména podíváme-li se na samotný Rámcový vzdělávací program pro základní vzdělávání (dále RVP) ${ }^{5}$ a na Manuál pro tvorbu školních vzdělávacích programů (dále Manuál k ŠVP) ${ }^{6}$. Jak RVP tak Manuál k ŠVP pracují s pojmem autoevaluace školy.

5 Rámcový vzdělávací program pro základní vzdělávání (se změnami provedenými k 1. 9. 2005; č.j. 25846/2005-2). In: http://www.vuppraha.cz/index.php?op=sections and sid=367.

6 Manuál pro tvorbu školního vzdělávacího programu pro základní vzdělávání. In: http://www.vuppraha.cz/index.php?op=sections and sid=295. 
Autoevaluace školy slouží, podle RVP, „k systematickému posuzování činnosti školy plánované ve školním vzdělávacím programu; výsledky slouží jako zpětná vazba ke korekci vlastní činnosti a jako východisko pro další práci školy; autoevaluaci prováději účastníci vzdělávacího procesu - vedení školy, učitelé, žáci" (s. 121). Tzv. evaluační činnosti RVP definuje jako "veškeré plánované a cílené aktivity školy směřujicí k ověřování, měření, posuzování a hodnocení výsledků a změn dosažených ve všech činnostech školy vymezených ve školním vzdělávacím programu,(s.121). Sled pojmů ověřování, měření, posuzování a hodnocení svědčí o jisté bezradnosti, kterou však definitivně završuje manuál $k$ tvorbě ŠVP, poněvadž chápe autoevaluaci „především jako průběžnou diskusi o tom, co se ve škole děje, o problémech, které je třeba řešit, i o způsobech jejich nápravy" (s. 72)7. Takovéto vymezení považuji za nepřijatelné, ve své podstatě znevažující samotný význam, úlohu i potenciální přínosy evaluačních procesů. Jisté zmírnění tohoto terminologického neporozumění přináší alespoň poznámky pod čarou, vysvětlující autoevaluaci jako "Vlastní plánovitou hodnotící činnost s pravidelně se opakujícími aktivitami, která je zaměřena na hodnocení práce školy za účelem zajištění kvality vzdělávání v rámci realizovaného vzdělávacího programu. Je možné ji proto chápat jako mechanismus soustavné autoregulace vlastní pedagogické práce" (s. 72). Slovní spojení zajištění kvality vzdèlávání považuji za významný, jedná se o ve své podstatě klíčový akcent evaluačních výzkumů (je o něm pojednáno níže). Opět je však evaluace mechanicky spojována s hodnocením a problematická definice kruhem ${ }^{8}$ uvádějící, že autoevaluace „představuje soubor pravidelně se opakujicich evaluačních aktivit zaměřených na sebehodnocení školy" (s. 72) je opět důkazem neporozumění a matoucí nejasnosti.

Mírnější objasnění uvádí do problematiky opět pod čarou uvedená definice pojmu evaluace. Již se blíží k vymezení evaluace jako výzkumného šetření (viz níže) a zdůrazňuje ji jako „činnost predstavující systematický sběr a analýzu dat poskytující škole informace potřebné pro zlepšení fungování jejího školního vzdělávacího programu a umožňuje ji lépe vnímat a uvědomovat si žádoucí změny, které by mohly přispět ke zvýšení efektivity programu. Prostřednictvím evaluace je umožněno pracovníkům školy, žákům i ostatním lidem mimo školu porozumět procesům, které ve škole probíhají, a tyto procesy zpětně ovlivňovat" (s. 72).

Tato poslední definice, zdá se, nejvíce přibližuje procesy (auto)evaluace výzkumným procedurám, na jehož průběh jsou kladeny vysoké nároky a vyžadují od realizátorů jisté specifické „výzkumné“ znalosti. Také další pojmy, se kterými Manuál v souvislosti s povinnostmi školy evaluovat školní vzdělávací program pracuje, mají své opodstatnění. Jedná se zejména o oblasti, cíle a kritéria evaluace (kritéria jsou však volně v některých částech textu zaměňována za indikátory kvality, což je diskutabilní - srov. s. 79, 81). Používaný pojem nástroje evaluace ve své podstatě nahrazuje pojmy výzkumná metoda a technika, které by byly vhodnější, pokud bychom přisoudili evaluaci význam výzkumného šetření.

7 Zvýraznění slovního spojení „průběžná diskuse“ použil autor citovaného Manuálu.

8 Definice kruhem je ve formální logice definována jako „logický klam, ve kterém se definice zpětně odkazuje na pojem, který má sama vysvětlovat,...,takto definovaný pojem pak nemá žádný smysluplný obsah" (In: "http://cs.wikipedia.org/wiki/Definice_kruhem). 
Mají-li mít zákonem stanovená práva a povinnosti hluboce ukotvenou hodnotu a respekt, jak je žádoucí a očekává se v otevřené společnosti „vědění", měla by být jejich tvorba i posuzování prímo spojena s jistou kritickou reflexí, která umožňuje profesní růst a kvalitativní proměňování legislativního rámce a tím i vědomí jeho významu. Hodnoty a významy procesů evaluace a autoevaluace jsou nezpochybnitelné a je více než žádoucí a také cenné, že se stávají v českém školství jeho nedílnou součástí. Je však potřebné stále upozorňovat na odbornou náročnost spojenou s těmito profesními činnostmi, jimž musí předcházet př́prava podpůrného systému podmínek, jež by učitelům umožnila realizovat tyto povinnosti na vysoké odborné úrovni (systém dalšího vzdělávání, supervize, pomoc a spolupráce s odborníky na pedagogický výzkum apod.) a se zachováním jejich vnitřní motivace (profesní satisfakce, prestiž učitelské profese a v neposlední řadě také pomoc materiální a finanční). Byt̆ dobře míněné, avšak jisté „zlehčování" požadavků a náročnosti, jež se $k$ autoevaluaci váží, může vyznívat jako alibistické vzhledem $k$ absenci výše zmíněné systémové podpory. Důsledky, a to zejména pro kvalitu a prestiž pedagogiky jako vědy a pedagogického výzkumu, však mohou být velmi nežádoucí, tristní. Bližší vysvětlení pro tato tvrzení jsou součástí následující kapitoly.

\section{Stanou se učitelé „výzkumníky“ ve svých třídách?}

Pokusme se nyní osvětlit blíže otázku, zda-li můžeme evaluaci považovat za typ výzkumu, popř. kdy a za jakých podmínek. Níže jsou uvedeny vybrané koncepce českých a zahraničních odborníků, jež akcentují výzkumný charakter evaluace a ve vztahu k ní rovněž explicitně vymezují výzkumné profesní činnosti a kompetence učitelů.

Podle J. Průchy (1996) a D. Nezvalové (2004) pokrývá obsahově pojem evaluace teoretický př́stup, zdůrazňující potřebu hodnotit všechny jevy edukační reality (např. vzdělávací procesy a programy, vzdělávací výsledky a instituce), dále metodologii tohoto hodnocení jako souboru výzkumných metod a technik a v neposlední řadě proces, $v$ němž se prostřednictvím zvolené metodologie realizuje teoretický př́stup, který se po volbě určitého edukačního jevu uskutečňuje na odpovídající úrovni vzdělávací praxe (např. vzdělávací program konkrétní školy nebo vzdělávací soustava jedné nebo více zemí). Evaluace je podle Průchy významově blízká vědecké a výzkumné oblasti, zatímco pojem hodnocení využívá každodenní školní praxe. „Evaluace (evaluation) je termín zavedený v oblasti teorie, vědy a výzkumu, kdežto hodnocení (assessment) je termín používaný spiše učiteli, rodiči a nepedagogickou veřejnosti" (1996:11). Termín evaluační výzkum používá rovněž M. Chráska (1995), a to ve spojitosti s „měření nejrůznějších pedagogických jevů, procesů nebo efektů." (s. 44). Jeden ze tří typů evaluace - vědecký výzkum, vedle kontroly a posuzování a procesu sebereflexe a plánování dalšího rozvoje, pojmenovává i K. Rýdl (1997). Představu o evaluaci jako procesu kontroly a posuzování prisuzuje zaběhlé zkušenosti učitelü, jež jsou sami spolu se svými žáky předmětem kontroly školních inspektorů, kteří zvenku diktují kritéria i postupy hodnocení a posuzování. Naproti tomu stojí zcela opačné pojetí evaluace jako procesu sebereflexe mající klíčový vý- 
znam v rozhodovacích procesech a aktech plánování a predikce dalšího rozvoje. Pojem sebereflexe podle Rýdla naznačuje, že aktéry a vykonavateli evaluace jsou její prímí účastníci, v prípadě školy pak její vedení, učitelé i žáci. Evaluace orientovaná na vědecký výzkum si dává za cíl posuzovat inovační procesy a projekty v pedagogické praxi a výsledky tak slouží „k zjištění míry aplikace sledovaného jevu do širšího systému" (Rýdl 1997:3). V podobném pojetí je nesena také koncepce J. Bennett (2003), jež považuje evaluační výzkum za novou disciplínu, která vznikla z neustále se zvyšujícího zájmu o evaluaci, a to zejména z důvodu její významné role, kterou sehrává v rozhodovacích procesech. „Evaluační výzkum přináší ucelený soubor důkazů, které osvětlují hodnoty nacházející se ve vzdělávacích programech, produktech a technologiích" (s.36).

Termín evaluační výzkum bývá zejména $v$ zahraničních zdrojích úzce spojován či prímo substituován také s dalšími obsahově blízkými typy edukačních výzkumů, jež jsou realizovány samotnými praktiky, a to ve více či méně těsné spolupráci s odborníky v pedagogickém výzkumu. Jedná se o pojmy akční výzkum (action research) ${ }^{9}$ a učitelský výzkum (teacher research) ${ }^{10}$. Není v záměru ani obsahových možnostech tohoto článku blíže se věnovat těmto konstruktům ${ }^{11}$, stručně je alespoň v poznámkách pod čarou uvedena charakteristika spolu s odkazy, jež blízkost s diskutovanou (auto)evaluací ukazuje. Podívejme se nyní alespoň na vybrané metodologické koncepty zaměřené na přímé terminologické propojení evaluačního výzkumu s výzkumem akčním a učitelským.

Slovník Pedagogické metodologie (Maňák, Švec, Švec 2005) přisuzuje evaluaci funkci sumativní a formativní, podobně jako u hodnocení. Sumativní funkce umožňuje popsat stav, v němž se předmět evaluace nachází, formativní funkce je potom spojena s hodnocením tohoto stavu a předchází formulování korektivních opatření. "Zdůrazněním formativní funkce se evaluace bliží akčnímu výzkumu“ (s. 34).

Odborníci z Virginia Commonwealth University J. H. McMillan a J. F. Wergin (1998) v publikaci "Understatnding and Evaluating Educational research (1998) radí evaluační výzkum (evaluation research) k typu akčního výzkumu spolu s tzv. výzku-

9 K premisám akčního výzkumu (action research) patří zejména jeho přímý podíl na řešení problémů vycházejících z potřeb (pedagogické) praxe. Má intervenční povahu, poněvadž svými důsledky zasahuje do (vzdělávací) reality a k jeho hlavním cílům patří poznat co možná nejkomplexněji všechny procesy a jejich kontexty reálné praxe a tím postulovat a navrhovat širokou škálu inspirativních řešení. Akční výzkumy „spojují akci ( výkon, děj) s výzkumem (bádáním, zkoumáním, objevováním) a vytvářejí mosty mezi skupinami účastníkü“ (Walterová 1995: 18); dále také Elliott 1981; Hendl 1999; Nezvalová 2002; Ferrance 2000). Je však zapotřebí zdůraznit, že akční výzkum (překládán také jako výzkum chování či jednání) definoval v polovině minulého století sociální psycholog Kurt Lewin. Snažil se poukázat na praktický význam vědy a vědeckého výzkumu umožňujícího realizovat smysluplné změny $v$ sociální realitě a dlouhodobě kontrolovat jejich působení (srov. Seebauer 2003). Akční výzkum není doménou pouze pedagogických věd a nemusí být realizován pouze učiteli a ve školské praxi. Volné substituování pojmů akční a učitelský výzkum není vhodný a měli bychom uvažovat o zakotvení učitelského výzkumu (teacher research) v typologii výzkumu pedagogického.

10 Ebbutt 1985; Spring 1993; Abdal-Hagg 1995; Parsons 1997; McMillan, Wergin 1998; Foster, Gomm, Hammersley 2000); podrobněji k učitelskému výzkumu a k výzkumné kompetenci učitelů také Seberová 2006, 2007.

11 Blíže jsou diskutovány např. v odkazech: Seberová 2006, 2007, 2008. 
mem pedagogické praxe (practice-based research) a volí ekvivalentní názvy učitelský výzkum (teacher research) nebo výzkum školní třídy (classroom research). Ve vztahu k akčnímu výzkumu autoři poukazují na důležitost využití jak kvalitativní, tak kvantitativní metodologie a rozdíl mezi evaluačním a učitelským výzkumem se podle nich netýká otázek jak je výzkum realizován, ale proč. Evaluační výzkum umožňuje odkrývat hodnoty jednotlivých edukačních programů a napomáhá tak $v$ rozhodování, zda-li by daný program měl být zachován, změněn nebo nahrazen jiným. Evaluační výzkum s tímto zaměřením pak zpravidla provádějí externí experti. Učitelský výzkum realizují sami učitelé - profesionálové - s cílem lépe poznat a porozumět vlastní pedagogické praxi a nacházet možnosti, jak ji zlepšovat. Výsledky obou forem akčního výzkumu mohou, podle autorů, indikovat změny školské praxe, a to i na státní úrovni ${ }^{12}$.

Další teoretický přístup je reprezentován D. Ebbuttem (1985), který zcela explicitně vymezuje rozdíly $v$ charakteristikách reflektivního vyučování (to nepovažuje za typ výzkumu) a učitelského výzkumu, který následně dělí na model autoevaluačního akčního výzkumu, "klasického" akčního výzkumu a tradičního výzkumu. Autoevaluační akční výzkum („self-evaluation“ action research) je realizován samotným učitelem s cílem porozumět a rozvíjet kvalitu vlastního vyučování, zavádí změny na elementární úrovni dané školní třídy. Klasický akční výzkum („„classical“ action research) řídí spolupracující tým aktérů školního společenství a přináší změny na institucionální úrovni. Tradiční učitelský výzkum (traditional action research) rovněž praktikují učitelé, reflektuje aspekty praxe, avšak selektuje hypotézy z formální teorie a "doufá", že tím přispěje $k$ její tvorbě a rozvoji. V následující tabulce jsou uvedeny Ebbuttem popsané rozdílné atributy u procesů reflektivního vyučování a autoevaluačního akčního výzkumu, čímž navážeme na výše popsané rozdíly v pojmech evaluace a hodnocení.

Tab. 2.

\begin{tabular}{|l|l|}
\hline Reflektivní vyučování & $\begin{array}{l}\text { Autoevaluační akční výzkum (jako druh uči- } \\
\text { telského výzkumu) }\end{array}$ \\
\hline realizován v izolaci vlastní školní třídy & realizován v izolaci vlastní školní třídy \\
\hline $\begin{array}{l}\text { reflektuje vlastní vyučování nepravi- } \\
\text { delně, (čas od času); využívá možnosti } \\
\text { zavádět do praxe změny }\end{array}$ & $\begin{array}{l}\text { pravidelné, systematické a řízené reflektování } \\
\text { vlastního vyučování; změny do praxe zavádí sys- } \\
\text { tematicky }\end{array}$ \\
\hline nesystematický sběr dat & systematický sběr dat \\
\hline & systematická analýza dat a vytváření hypotéz \\
\hline nepíše se výzkumná zpráva & $\begin{array}{l}\text { píše se výzkumná zpráva otevřená k veřejnému } \\
\text { posouzení }\end{array}$ \\
\hline $\begin{array}{l}\text { implementuje reflexe do praxe „čas od } \\
\text { času“ }\end{array}$ & $\begin{array}{l}\text { systematicky implementuje výsledky výzkumné } \\
\text { reflexe s následnou změnou praxe }\end{array}$ \\
\hline
\end{tabular}

12 Evaluační výzkum je v těchto dokumentech vztahován k posuzování hodnot a kvalit edukačních programů, což odpovídá také našemu legislativnímu vymezení školních vzdělávacích programů a povinnostem jejich evaluace. Předměty pedagogické evaluace (jak jsou v uvedených publikacích zmiňovány) však přesahují hranice edukačních programů a vztahují se prakticky k celé pedagogické realitě. 
(srov. Ebbutt 1985)

Podobnost s výše uvedenými odlišnostmi v charakteristikách hodnocení (assesment) -jako běžného posuzování a reflexe a evaluace (evaluation), myslím, není potřeba komentovat. Akcent na dodržování jistých metodologických zásad, řizené plánování, průběh šetření i kontrola výstupů s důrazem na realizovatelnost a výsledné efekty implementovaných změn bezpochyby dodává (auto)evaluaci ráz výzkumného šetření, jehož kvalitu je zapotřebí chránit s ohledem na prestiž pedagogického výzkumu v doméně společenských věd. Za důležité však považujeme důsledně se podívat na stávající pojetí pedagogické metodologie a zejména typologii pedagogických výzkumů, a to zejména ve vztahu k místu, které v něm zaujímá výzkum evaluační a učitelský (evaluation research, teacher resarch, popř. practicebased research, classroom research apod.).

Pokud bychom se blíže podívali na specifika (auto)evaluačních výzkumů ve srovnání s dalšími typy výzkumů pedagogických, mohli bychom poukázat na vázanost s předem danou, jasně definovanou hodnotou jako kvalitou a efektivitou každého konkrétního jevu a procesu coby předmětu (auto)evaluace. Charakteristika indikátorů kvality a efektivity je považována za hlavní kritérium úspěšné realizace evaluačních výzkumných šetření. ${ }^{13}$ "Evaluační aktivity v oblasti vzdělávání jsou vždy vázány na poměřování s nějakými hodnotami, vzory, ideály,..., nastal čas k dưkladnému objasňování toho, co chceme chápat jako žádoucí hodnoty vzdělávání- dnes a pro budoucnost. Bez toho objasnění a prijetí hodnot by sebedokonaleji evaluační procedury zůstaly jen technickými instrumenty" (Průcha 1996:152).

Z uvedených argumentů vyplývá, že je možné, vhodné i žádoucí respektovat evaluaci jako typ výzkumu, jehož cílem je popsat a vysvětlit zkoumané edukační jevy, poznat a posoudit jejich kvalitu a efektivitu jako znaky hodnoty a v neposlední radě navrhovat opatření, kterými se tyto hodnoty mohou zvyšovat. Jasně definovaná kvalita zkoumaných jevů, jasně vymezené indikátory této kvality a kritéria pro jejich posuzování se musí stát východiskem pro takovýto typ výzkumu. Je zapotřebí předejít nežádoucím modifikacím významů evaluačních procesů, nároků na jejich realizaci i místa, jež mohou sehrávat v oblasti pedagogického vědeckého výzkumu.

\section{Závěrem}

Každá škola jako vzdělávací instituce je kulturou svého druhu, originálním a jedinečným společenstvím lidí nesoucích zodpovědnost za kvalitu svého života. Jis-

13 Kvalita je definována jako žádoucí, optimální úroveň či stupeň dokonalosti. Pomáhají ji charakterizovat jasně vymezené indikátory a kritéria pro jejich výzkumnou posouditelnost. V souvislosti s posuzováním celkové kvality práce školy se uvádí také termín efektivnost školy (school effectiveness) a označuje klíčové kritérium její kvality. Efektivnost je vysvětlována ve dvou kategoriích. Jednak jako „výkonnost“ nebo též orientace na činnost (efficiency) zohledňující procesuální stránku dosažených výsledků analýzou vynaložených prostředků, které k danému výsledku dopomohly; a jednak jako efektivita (efectiveness) orientující se na cíl, resp. na porovnávání cílů s dosaženými výsledky (srov. Fischer, Schratz, 1997; Průcha 1996). 
tá individualita podmínek, v nichž se škola nachází, osobnostní a profesní profily učitelů a ředitelů, sociokulturní a osobnostní charakteristiky žáků a jejich rodičů více či méně ovlivňují výsledky práce školy i specifické problémy s nimiž se potýká, a které vyžadují specifické způsoby řešení. Významy evaluace a autoevaluace pro školskou praxi jsou nemalé, stejně jako důsledky její neodborné realizace pro pedagogický výzkum. Je více než žádoucí, aby rostla kvalita a prestiž učitelské profese, aby naši učitelé byli odborně způsobilí realizovat kvalitní autoevaluační výzkumy ve svých školách, třídách. Umožní jim postihnout individuální zvláštnosti každé jednotlivé školy a poznat její skutečné možnosti, rizika i příležitosti. Otevřou príležitost konstruktivním změnám a efektivnímu učení, poněvadž zprostředkovávají kritický pohled vlastníma očima. Usnadňují rozhodování, posilují otevřenost a důvěru všech aktérů školy a rozvoj pozitivní pracovní kultury a možnosti školy stát se otevřenou a respektovanou výchovně vzdělávací institucí s jasnými představami smyslu své existence - „učící se organizací". V neposlední řadě vytvárí autoevaluační učitelské výzkumy prostor k růstu prestiže učitelství i k zvyšování profesního sebevědomí učitelů, což není v době dnes hodně diskutované „krize“ učitelské profese jistě zanedbatelné.

\section{Literatura}

Abdal-Hagg, I. Eric as resource for the teacher Researcher. Eric digest. In: http:// ericdigest.org/1993/researcher.htm

Bennett, J. Evaluation: A Multi-method Evaluation. Continuum International Publishing Group 2003. ISBN 0826464785.

Borich, H. D.; Madden, S. K.: Evaluating Classroom Instruction. Addison, Wesley 1977.

Donaldson, G. (ed.). Quality Management in Education - Self-Evaluation for Quality Improvement. Livingston, HMIE: 2006. ISBN 80-7053-1087-6.

Ebbutt,D. Educational action research: Some general concerns and specific quibbles. In Burgess, R.G. (Ed.) Issues in Educational research qualitative methods. Philadelphia,PA: Falmer Press, 1985.

Elliott, J. Action - research: A framework for self-evaluation in schools. TIQL - Working Paper No.1. Cambridge: Institute fo Education, 1981.

Farrell, T. Reflective Teaching. The principles and practices. In: http://exchanges.state.gov/forum/vols/vol36/no4/p10.htm

Ferrance, E. Action research. Themes in Education. Northeast and Islands regional Educational Laboratory. Brown University 2000.

Fischer, A.W.; Schratz, M.: Vedení a rozvoj školy. Brno, Paido 1997.

Foster, P., Gomm, R., Hammersley, M. Case studies as spurious evaluations: The example of research on educational inequalities. British Journal of Educational Studies. Vol. 48, No. 3, s. 215-230, 2000. ISSN 0007-1005.

Gall, M. D.: Handbook of Evaluating Selecting Curriculum Materials. Boston, Aleyn and Bacon INC 1981.

Hendl, J. Úvod do kvalitativního výzkumu. Praha : Karolinum,1999. ISBN 80-246- 
0030-7.

Chráska, M.: K současným trendům pedagogického výzkumu ve světě. Olomouc, UP 1995.

Kasáčová, B. Reflexívna výučba a reflexia v učitel'skej príprave. Banská Bystrica: Pedagogická fakulta Univerzity Mateja Bela v Banskej Bystrici, 2005. ISBN 80-8083046-0.

MacBeath, J., Schratz, M., Meuret, S., Jakobsen, L. Serena aneb autoevaluace škol v Evropě. Ždár n. Sázavou, Fakta: 2006. ISBN 80-902614-8-5.

Manuál pro tvorbu školního vzdělávacího programu pro základní vzdělávání. In: http://www.vuppraha.cz.

Maňák, J., Švec, Š., Švec, V. Slovník pedagogické metodologie. Brno: Paido, 2005. ISBN 80-7315-102-2.

McBride, R. Úvod do kvalitativního výzkumu. Průvodce pro učitele. Liberec, PdF TU Liberec: 1995. ISBN 80-7083-183-9.

McMillan, J.H.; Wergin, J.F. Understanding and Evaluating Educational Research. New Jersey: Columbus, Ohio, Merrill, 1998. ISBN 0-13-193541-0.

Nezvalová, D. Kvalita 2004. Nový Jičín, KVIC: 2004. nepublikováno.

Nezvalová, D., Kunčarová, J. Ověřování kvality školy. Ostrava, Ostravská univerzita v Ostravě: 2006. ISBN 80-7368-198-6. (a)

Nezvalová, D., Kunčarová, J. Vlastní hodnocení školy. Klíc k vyhodnocení ukazatelů. Ostrava, Ostravská univerzita v Ostravě: 2006. ISBN 80-7368-245-1. (b)

Nezvalová, D., Kunčarová, J. Vlastní hodnocení školy. Hlavní oblasti - soubor ukazatelů. Ostrava, Ostravská univerzita v Ostravě: 2006. ISBN 80-7368-197-8. (c)

OECD/CERI. Školy pod lupou. OECD 1995. ISBN 80-211-0239-X

Parsons, S. Teacher research. In: http://www.accessexcellence.org/LC/TL/AR/ 1997.

Pol, M. Škola v proměnách. Brno: MU 2007. ISBN 978-80-210-4499-9.

Pollard, A. Reflective teaching in the Primary school. London: Cassell, 1998. ISBN 0-304-33870-2.

Pring, R. Editorial: Educational research. British Journal of Educational Studies. Vol. 48, No. 1, s. 1-10, 2000. ISSN 0007-1005.

Průcha, J.: Pedagogická evaluace. Brno, MU 1996.

Průcha, J.; Walterová, E.; Mareš, J.: Pedagogický slovník. Praha, Portál 1998. ISBN 80-7178-252-1.

Rýdl, K.; Horská, V.; Dvořáková, M.: Autoevaluace školy (Příručka pro rozvoj hodnocení kvality školy). Praha 1997. Grantová studie pro MŠMT ČR.

Seberová, A. Výzkumná kompetence v učitelské profesi a ve vzdělávání učitelů. Ostrava: PdF OU 2006. ISBN 80-7368-270-2.

Seberová, A. Reflektivní vyučování, akční nebo učitelský výzkum? In Svět výchovy a vzdělávání v reflexi současného pedagogického výzkumu. Jihočeská univerzita v Českých Budějovicích, 2007. ISBN 978-80-7394-061-4.

Seberová, A. Evaluace ve školské praxi. Ostrava: PdF OU 2008. ISBN 978-80-7368-556.

Seberová, A. Učitelský výzkum? (v kontextu metodologie pedagogických věd a možnostech učitelské profese. In: Sborník přispěvků vědecké konference ČAPV Pedagogický výzkum jako podpora proměny současné školy. Hradec Králové: PdF 
UHK 2008.

Seebauer, R. Základní úvahy o plánování, realizaci a vyhodnocování vědeckých výzkumů prováděných v rámci diplomových prací a disertací. Brno: Paido, 2003. ISBN 80-7315-056-5.

Spring, J. American education. New York: McGraw-Hill, 1994. ISBN 0-07-060551-3.

Švec, V. Cesty k učitelské profesi: utváření a rozvíjení pedagogických dovedností. Brno: Paido 2002. ISBN 80-7315-035-2.

Walterová, E. Akční výzkum v podmínkách české školy. Praha: 1995.

Weiss, E. M., Weiss, S. Doing Reflective Supervision with Student Teachers in a Professional Development School Culture. Reflective Practice. Vol.2, No.2,2001, s. 125-154. ISSN 1462-3943. 